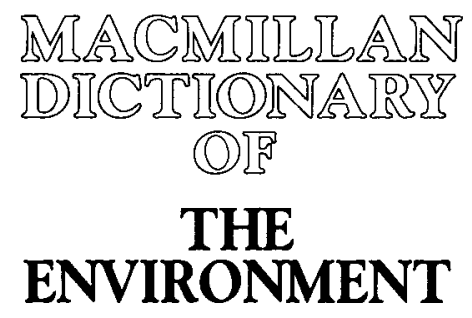




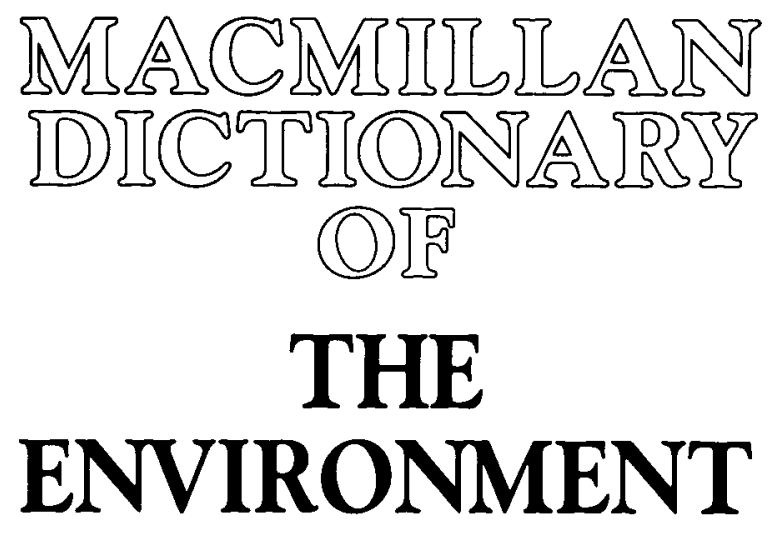

FOURTH EDITION

MICHAEL ALLABY 
(C) Michael Allaby, 1977, 1983, 1988, 1994

All rights reserved. No reproduction, copy or transmission of this publication may be made without written permission.

No paragraph of this publication may be reproduced, copied or transmitted save with written permission or in accordance with the provisions of the Copyright, Designs and Patents Act 1988, or under the terms of any licence permitting limited copying issued by the Copyright Licensing Agency, 90 Tottenham Court Road, London W1P 9HE.

Any person who does any unauthorised act in relation to this publication may be liable to criminal prosecution and civil claims for damages.

First edition published 1977, paperback 1979.

Second edition published 1983, paperback 1985.

Third edition published 1988, paperback 1988.

Reprinted 1991.

Fourth edition first published 1994 by

THE MACMILLAN PRESS LTD

London and Basingstoke

Associated companies in Auckland, Delhi, Dublin, Gaborone, Hamburg, Harare, Hong Kong, Johannesburg, Kuala Lumpur, Lagos, Manzini, Melbourne, Mexico City, Nairobi, New York, Singapore, Tokyo.

A catalogue record for this book is available from The British Library.

ISBN 978-0-333-61655-0 ISBN 978-1-349-13495-3 (eBook)

DOI 10.1007/978-1-349-13495-3 


\section{Preface to the Fourth Edition}

During the six years that have passed since the publication of the third edition of the Dictionary of the Environment the study of environmental sciences has established itself firmly in the curricula of most schools, although not always under that formal name. Environmental sciences also feature in many courses in further and higher education undertaken by students whose careers will require them to understand the environmental effects of human activities and the laws and regulations intended to control those effects. If, as some believe, there was once a time when people carelessly regarded their surroundings as no more than a source of materials and repository for their wastes, that time is long past. Today, planners, builders, manufacturers, providers of services, and you and I as householders are required to take account of the environmental consequences of our actions. This, of course, is as it should be.

As comment on environmental matters has advanced from pious exhortation to practical application, the language employed has grown more technical. The intensification of scientific research has generated new expressions, many of which occur in newspapers and broadcasts, along with a proliferation of organizations, regulations, and acronyms. In this revision of the Dictionary I have added most of the scientific terms and organizations that have emerged since the last edition. Scientific terms have been identified partly from scientific journals and textbooks on environmental sciences. The newly added organizations and acronyms include those associated with the 1992 United Nations Conference on Environment and Development (UNCED), which was variously nicknamed the 'Earth Summit' and 'Rio Summit' (after the city in which it was held).

Preparation of a dictionary begins with a definition of its scope. When the first edition of this Dictionary was planned, the 'environment' was assumed to comprise the rocks and land-forms of the Earth's surface, the oceans and atmosphere, living organisms, industrial and technological processes, organizations, and concepts derived from economics. Within this vast framework, a small team of contributors and advisers attempted to select a necessarily limited number of the most relevant terms. This produced a general structure that has survived through subsequent revisions, including this one.

Retention of the essential structure implies no lack of rigour in making revisions, and this revision has been very thorough. I have added many new entries, removed some earlier ones, and altered a large number, sometimes substantially, to clarify them or bring them up to date. Some of the taxonomic terms, for example, have been modified to take account of recent changes in classification. Every entry has been studied carefully and where I saw room for improvement I made it. I have added those environmental disasters which occurred since the last edition, both as entries in their own right and in summary form in the table of 'environmental disasters', which I introduced in the Third Edition and have retained.

As with the last edition, for this revision I have not approached those who contributed entries to the earlier editions. The revisions are my own and I must bear responsibility for any errors I may have introduced. Nevertheless, many of the definitions included here are essentially those contributed and verified by Ailsa Allaby, Dr G. Browning, Dr M.D. Hooper, John Macadam, Margaret Palmer, Professor F. Roberts, Professor R.S. Scorer, and Professor E.K. Walton, to whom I remain deeply grateful. 